\title{
Effects of sex hormone-binding globulin (SHBG) on androgen bioactivity in vitro
}

Michaël R. Laurent, ${ }^{1,2}$ Christine Helsen, ${ }^{1}$ Leen Antonio, ${ }^{1,3}$ Dieter Schollaert, ${ }^{1}$ Steven Joniau, ${ }^{4}$ Michel J. Vos, ${ }^{5}$ Brigitte Decallonne,${ }^{3}$ Geoffrey L. Hammond, ${ }^{6}$ Dirk Vanderschueren, ${ }^{3}$ and Frank Claessens ${ }^{1 *}$

${ }^{1}$ Laboratory of Molecular Endocrinology, Department of Cellular and Molecular Medicine, KU Leuven, Herestraat 49 PO box 901, 3000 Leuven, Belgium

${ }^{2}$ Gerontology and Geriatrics, Department of Clinical and Experimental Medicine, KU Leuven, Herestraat 49 PO box 7003, 3000 Leuven, Belgium

${ }^{3}$ Clinical and Experimental Endocrinology, Department of Clinical and Experimental Medicine, KU Leuven, Herestraat 49 PO box 902, 3000 Leuven, Belgium

${ }^{4}$ Laboratory for Experimental Urology, Organ Systems, Department of Development and Regeneration, KU Leuven, Herestraat 49 PO box 7003-41, 3000 Leuven, Belgium

${ }^{5}$ Laboratory Medicine, University Medical Centre Groningen, Hanzeplein 1 PO box 30001, 9700 RB Groningen, The Netherlands

${ }^{6}$ Department of Cellular and Physiological Sciences, University of British Columbia, 2350 Health Sciences Mall, V6T 1 Z3 Vancouver, B.C., Canada

\section{Corresponding author:}

Prof. dr. Frank Claessens

Laboratory of Molecular Endocrinology, KU Leuven

Herestraat $49 \mathrm{PO}$ box 901

3000 Leuven

Belgium

frank.claessens@med.kuleuven.be

Tel +3216330253

Fax +3216330735 


\section{ABSTRACT}

Biochemical assessments of androgen status (hyper- or hypoandrogenism) are usually based on serum testosterone concentrations. According to the free hormone hypothesis, sex hormone-binding globulin (SHBG) determines free and bioavailable testosterone concentrations. Previous studies have suggested that in vitro androgen bioassay results may also be influenced by SHBG and correlate with free or bioavailable testosterone concentrations. To test this hypothesis, we established a stable HEK293 cell line with high expression of the human androgen receptor (AR) and a luciferase reporter downstream of a classical androgen response element. Importantly, we demonstrate that bioassay results are sensitive to dilution effects which increase apparent bioactivity in an SHBG-dependent manner. We therefore adopted a method using undiluted serum, which reduced cell proliferation but did not significantly affect the luciferase signal, cell viability or cytotoxicity. To correct for serum matrix effects, we applied signal correction based on internal controls with AR agonists or antagonists. Using this method, we provide direct evidence that in vitro androgen bioactivity reflects the inhibitory effects of SHBG, and correlates with free or bioavailable testosterone concentrations in adult hypogonadal men receiving androgen replacement therapy. In men receiving anti-androgens, serum bioactivity decreased tenfold while serum testosterone concentrations decreased only four-fold. Further pilot results in prostate cancer patients showed that androgen synthesis inhibitors result in more complete inhibition of androgen bioactivity than gonadorelin-based androgen deprivation therapy, even in patients whose testosterone concentrations were undetectable by mass spectrometry. We conclude that in vitro androgen reporter bioassays are useful tools to study how androgen bioactivity in serum is determined by androgens, anti-androgens as well as SHBG, provided that dilution and matrix effects are accounted for.

\section{Keywords}

Androgen receptor; Androgens; Bioassay; Luciferase; Sex hormone-binding globulin 


\section{INTRODUCTION}

Androgens are endogenous $\mathrm{C} 19$ steroid hormones which activate the androgen receptor (AR) and elicit important biological functions in reproductive and other sexually dimorphic tissues (Pihlajamaa et al., 2015). Upon ligand binding in the cell cytoplasm, the AR dimerizes, translocates to the nucleus, binds to specific DNA sequences called androgen response elements (AREs) and recruits coregulators to activate transcription of its target genes (Helsen and Claessens, 2014, Pihlajamaa et al., 2015). Two types of AREs exist: classical and selective AREs, which are either conserved or partially conserved repeats of the 5'-AGAACA-3' consensus sequence separated by a three-nucleotide spacer. Classical AREs can be recognized by other nuclear receptors like the glucocorticoid or progesterone receptor, while only AR can bind selective AREs to elicit transcriptional programs specific to e.g. male reproductive organs (Denayer et al., 2010, Kerkhofs et al., 2012, Pihlajamaa et al., 2015, Sahu et al., 2014, Schauwaers et al., 2007).

The AR is mainly a ligand-dependent transcription factor whose biological effects largely depend on the time and degree of AR occupancy by different ligands (Clinckemalie et al., 2012). Serum testosterone $(\mathrm{T})$ concentrations are the primary method to judge androgen status in clinical practice (Snyder et al., 2016). In addition to T and its more active metabolite, $5 \alpha$-dihydrotestosterone (DHT), androst-4-ene-3,17-dione (Adione) or androst-5-ene-3 $\beta, 17 \beta$-diol (Adiol) are endogenous androgens or androgen precursors that are also present in the circulation, and recent studies suggest that measuring these androgens may also contribute to the assessment of androgen bioactivity (Munzker et al., 2015, O'Reilly et al., 2014). Importantly, the bioavailability of circulating sex steroids is thought to be inhibited by sex hormone-binding globulin (SHBG) (Mendel, 1989). This $\sim 45 \mathrm{kDa}$ glycoprotein has high (nM $K_{d}$ ) binding affinity for DHT, T and estradiol (E2) (Wu and Hammond, 2014). On average, about $45 \%$ of circulating T or E2 is bound to SHBG in normal adult men and women, respectively. This fraction is considered biological unavailable, while non-SHBG-bound steroids constitute the bioavailable fraction. This bioavailable fraction is mainly bound with low affinity to bulk carrier proteins like albumin and only 1-3\% circulates freely (i.e. non-protein-bound) (Dunn et al., 1981, Hammond et al., 2012, Rosner et al., 2007, Siiteri et al., 1982, Vermeulen et al., 1999). According to the free hormone hypothesis however, only non-protein-bound or "free" steroid hormones can diffuse into target cells and activate their cognate nuclear receptor (Mendel, 1989). Thus, SHBG is regarded as an important regulator of circulating sex steroid bioactivity. In clinical practice, free $T$ and/or bioavailable $T$ 
(bioT) and E2 concentrations are routinely calculated from total sex steroid and SHBG concentrations (Rosner et al., 2007, Rosner et al., 2013). However, growing concern surrounds this approach (Heinrich-Balard et al., 2015, Laurent and Vanderschueren, 2014, Zakharov et al., 2015). For example, several non-synonymous single nucleotide polymorphisms (SNPs) in the SHBG gene have been identified recently which may influence androgen binding affinity and thus free $T$ concentrations (Ohlsson et al., 2011, Wu and Hammond, 2014).

The golden standard to measure androgen bioactivity is an in vivo androgen bioassay called the Hershberger test, which involves test compound administration to castrated rats and post-mortem evaluation of the animals' accessory sex organs (Marty and O'Connor, 2014). In vitro bioassays can replace the use of laboratory animals to a certain extent, but their main advantage is that they are more practical for high-throughput screenings (Roy et al., 2008, Voet et al., 2013), screening for steroid abuse in athletes (Bailey et al., 2016, Cooper et al., 2013) or for potentially endocrinedisrupting compounds in environmental samples (Christiaens et al., 2005). In vitro bioassays can be classified as proliferation assays (e.g. proliferation response of an androgen-sensitive prostate cancer cell line) or reporter assays (e.g. based on transactivation of a luciferase construct, which offers more direct evidence of AR-mediated signaling). Furthermore, bioassays have been established using different mammalian or yeast cell lines; the latter may provide an advantage when metabolism and detection of precursor androgens like Adione, Adiol and dehydroepiandrosterone (DHEA) is desired (e.g. for hormone abuse screening in livestock or athletes), although the thick yeast glycocalyx may hinder diffusion into target cells (Soto et al., 2006). In vitro bioassays are most used for screening compounds in drug development or endocrine disruptor research, but they have also been applied to study circulating androgen bioactivity (Roy et al., 2008). It has been suggested that results from in vitro androgen bioassays also reflect the influence of SHBG (Liimatta et al., 2014, Raivio et al., 2001, Roy et al., 2006), but this has not been tested directly. One concern in this regard is the fact that most AR bioassays are conducted in the presence of diluted serum samples to $1-10 \%$ (with one notable exception using undiluted serum (Need et al., 2010). Previous studies on equilibrium dialysis have shown that dilution may disturb the equilibrium between SHBG and its ligands (Van Uytfanghe et al., 2004), but whether dilution also affects AR bioassay results is not known. Another important factor identified previously are matrix effects (Paris et al., 2002a, Roy et al., 2006) that are well known in clinical chemistry. Matrix effects can be defined as 
serum sample components which are unrelated to the analyte of interest per se (in this case, androgen bioactivity) but still produce unwanted alterations of the bioassay read-out. Considering this background, the aim of this study was to establish an androgen reporter bioassay to study the effects of SHBG on androgen bioactivity in vitro, and to validate our bioassay method in pilot studies using patient samples with particular attention to dilution and matrix effects.

\section{MATERIALS AND METHODS}

\subsection{Hormones and chemicals}

T, DHT, Adiol, Adione, R1881 (methyltrienolone), mibolerone, medroxyprogesterone acetate, E2, progesterone, dexamethasone, hydrocortisone, DHEA and DHEA-sulphate, ethanol, dimethylsulfoxide (DMSO) and ionomycin were purchased from Sigma-Aldrich. MENT (7a-Methyl-19-Nortestosterone) was a kind gift from dr. N. Kumar of the Population Council (New York, NY, U.S.A.). Enzalutamide was purchased from Sequoia Research Products (Pangbourne, U.K.).

\subsection{Cell lines and culture conditions}

Human embryonic kidney (HEK)-293 and VCaP cells were obtained from the American Type Culture Collection (Manassas, VA) and cultured as described before (Haelens et al., 2001).

\subsection{Stable cell line selection}

HEK-293-based T-Rex ${ }^{\circledR}$ cell lines stably expressing four copies of three different classical or selective AREs were selected with hygromycin $(50 \mu \mathrm{g} / \mathrm{mL}$, Thermo Fisher Scientific, Waltham, MA, U.S.A.) as described previously (Denayer et al., 2010). Cells were subsequently transfected by random integration with a full-length human AR cDNA construct inserted into the pSG5 vector (Christiaens et al., 2005) using GeneJuice ${ }^{\circledR}$ (Novagen, Merck, Darmstadt, Germany) as previously described (De Bruyn et al., 2011). The next day, cells were sparsely seeded in 6-well plates. Following selection with G418 (600 $\mu \mathrm{g} / \mathrm{mL}$, Thermo Fisher Scientific, Waltham, MA, U.S.A.), colonies showing androgeninduced luciferase activity were screened using firefly D-Luciferin-containing medium $(150 \mu \mathrm{g} / \mathrm{mL}$, Caliper Life Sciences) on the IVIS bioluminescence system. Isolated, luciferase-positive colonies were picked, clonally expanded and evaluated for androgen-induced luciferase activity. AR protein expression was verified by Western immunoblotting on whole-cell extracts.

\subsection{Luciferase experiments}


LARA cells were cultured in phenol-red free Dulbecco's modified Eagle's medium (DMEM) with $4.5 \mathrm{~g} / \mathrm{L}$ glucose (Thermo Fisher Scientific, Waltham, MA, U.S.A.), supplemented with 10\% fetal calf serum, penicillin, streptomycin and glutamin as described (Christiaens et al., 2005). Following trypsinization, cells were counted with a TC-20 Automated Cell Counter (Bio-Rad, Hercules, CA, U.S.A.) and seeded at 5'000 cells/well in similar media with 5\% dextran-coated charcoal-stripped FCS (DCC-FCS) into half-area 96-well cell culture plates (Greiner Bio-One, Kremsmünster, Austria). The next evening, media were replaced with various serum, medium and hormone concentrations as described below. T standard curves were prepared in 10-12 different T concentrations in undiluted DCC-FCS, and concentrations were validated by in-house liquid chromatography tandem mass spectrometry (Antonio et al., under review). Each standard and unknown was analyzed using six replicate wells. The minimal optimal volume was determined at $10 \mu \mathrm{L} /$ well (data not shown). As an internal control for matrix effects, each patient serum sample was analyzed after spiking with either DHT $10^{-6} \mathrm{M}$ or enzalutamide $10^{-5} \mathrm{M}$ as an internal control to adjust the corresponding 1:1000 vehicle-spiked sample for matrix effects (see Fig. 4, Suppl. Fig. 3 and Fig. 5 below, respectively). After 14-16h of incubation, media were removed, cells were lysed and arbitrary luciferase units (ALU) were quantified as described (De Bruyn et al., 2011) on a Luminoskan Ascent microplate luminometer (Thermo Fisher Scientific). The results were analyzed as described in the statistics section below.

\subsection{Cell viability and toxicity assays}

Cell viability was assessed by XTT assay (Applichem, Darmstadt, Germany) and cytotoxicity was assessed using the CellTox ${ }^{\mathrm{TM}}$ Green dye (Promega, Fitchburg, WI, U.S.A.) according to the manufacturer's instructions.

\subsection{Thymidine incorporation assay}

Cell proliferation was assessed by measuring ${ }^{3} \mathrm{H}$-labelled thymidine incorporation as a surrogate of DNA replication. LARA cells were seeded in 96-well plates (Cellstar; Greiner Bio-One) in medium containing $10 \%$ DCC-FCS. The next evening, media were replaced by different percentages of human serum supplemented with ${ }^{3} \mathrm{H}$-thymidine (PerkinElmer, Waltham, MA, U.S.A.). Sixteen hours later, media were removed and cells were rinsed, followed by trypsinization and transfer to a new multiwell plate using a cell harvester (Filtermate 196, Packard, Meriden, CT, U.S.A.). Fifty microlitres of liquid scintillation fluid (Microscint-O, Packard) was added to each well and disintegrations were counted using a microplate scintillation counter (Packard Topcount) as described previously (Helsen et al., 
2012). Measurements were corrected for background in wells without cells $(<1 \%)$ as well as values of input media used for stimulation, and expressed as percentage of the $5 \%$ serum condition.

\subsection{SHBG protein}

Since most mammals except mice and rats express Shbg post-natally in their livers, we obtained serum from six Wistar rats castrated for 3 weeks, as well as from heterozygous human SHBGtransgenic (Jänne et al., 1998) and wild-type control littermate male mice. Two mice of each genotype were orchidectomized at 20 weeks of age. Following euthanasia at 24 weeks, serum was obtained by cardiac puncture and pooled per genotype. The Animal Ethical Committee of KU Leuven approved all procedures (P160/2012), and mice were bred and used in accordance with current Belgian national and European directives. Serum from the orchidectomized rats was spiked with either $1.6 \%$ serum of castrated SHBG-transgenic mice (to obtain a $50 \mathrm{nM} \mathrm{SHBG}$ final concentration) or $1.6 \%$ serum from wild-type mice, to obtain a pure serum matrix with or without human SHBG. Both sera were spiked with $10 \mathrm{nM} \mathrm{T}$ and tested for androgen bioactivity either undiluted or at various serum dilutions as described below (see Fig. 2A below). A similar setup using serum of orchidectomized rats and orchidectomized SHBG-transgenic and WT mice was used to test the effect of SHBG on various hormone mixtures in undiluted serum (see Fig. 3C below). Alternatively, recombinant human SHBG (>95\% purity SDS-PAGE from Alpha Diagnostic Intl. Inc., San Antonio, TX, USA) was added to serum from a recently described man with complete SHBG deficiency (Vos et al., 2014) (see Fig. 3A below). To test the effect of SHBG mutants, HEK-293 cells were transiently transfected as described above with expression plasmids for SHBG WT, R123H, R123C, T7N, S42L, P156L or the empty pRc/CMV vector as described previously (Avvakumov et al., 2010, Hong et al., 2011, Ohlsson et al., 2011, Wu and Hammond, 2014). Two days after transfection, conditioned media were collected and concentrated using Amicon Ultra-4 centrifugal ultrafiltration units with 30'000 molecular weight cut-off filters (Merck Millipore).

\subsection{Patient samples}

Following approval by the University Hospitals Leuven Medical Ethical Committee (s54034, ClinicalTrials.gov number NCT02434562), a prospective biobank was set up to obtain serum for analysis. All patients provided written informed consent. Men starting androgen deprivation or replacement therapy were recruited from the Department of Endocrinology and prostate cancer patients were recruited from the Department of Urology, University Hospitals Leuven, Belgium. Human 
serum was obtained from two healthy male volunteers undergoing maintenance flebotomy for wellcontrolled hereditary hemochromatosis without end-organ complications.

\subsection{Testosterone and SHBG measurements}

Serum T and SHBG concentrations were measured on a Roche Modular E clinical immunoassay platform at the Department of Laboratory Medicine of the University Hospitals Leuven. T was measured with an in-house liquid chromatography tandem mass spectrometry (LC-MS/MS) method based on atmospheric pressure chemical ionisation (Antonio et al., manuscript submitted) with a limit of quantification of $2.5 \mathrm{ng} / \mathrm{dL}$ for total $\mathrm{T}$ and imprecision $<5 \%$. Free $\mathrm{T}$ and bioT were calculated according to (Vermeulen et al., 1999) with albumin fixed at a constant $4.3 \mathrm{~g} / \mathrm{dL}$ using the online calculator at http://www.issam.ch/freetesto.htm . The SHBG concentrations in conditioned media from cells transfected with various SHBG expression plasmids were cross-validated by measurement on a different clinical immunoassay platform (Siemens Immulite 2000) as well as by Western blot using an in-house primary polyclonal rabbit anti-human SHBG antiserum (1:100 diluted in 3\% milk protein) obtained using standard techniques (Marivoet et al., 1990).

\subsection{Statistical analyses}

All analyses were performed using Graphpad Prism v5.04. Mean and standard error (SEM) of 2-3 experiments are shown as specified. Standard curves were fitted with asymmetric (Richard's fiveparameter) dose-response curves using $1 / Y^{2}$ weighing and interpolation of individual unknowns. The luciferase values obtained from unknown samples were interpolated on the T standard curves and expressed as "T bioequivalents", defined as the corresponding T concentration for a certain luciferase value on the T standard curve. We corrected for matrix effects in the experiment with different conditioned media of cells transfected with SHBG mutants (Fig. 3B) using the luciferase values observed after spiking with $10^{-6} \mathrm{M}$ R1881 (which did not however influence the results, data not shown). Patient samples (see Fig. 4) were corrected for matrix effects by dividing each replicate by the ratio between the $10^{-6} \mathrm{M}$ DHT-spiked serum sample average and the $10^{-6} \mathrm{M} \mathrm{DHT}$ - or T-spiked DCCFCS average (see also Suppl. Fig. 3). Differences in continuous variables were analyzed using oneway ANOVA with Bonferroni's post-test, or Kruskal-Wallis test with Dunn's multiple comparisons test when variances were unequal. For categorical variables, differences in proportions were assessed by chi-square $\left(\mathrm{X}^{2}\right)$. For experiments involving matched values, differences in one continuous variable between two or more groups were analyzed by Wilcoxon matched-pairs signed rank test or repeated 
measures (RM) ANOVA with Dunnett's post-test, respectively. To study interaction between two variables, two-way RM ANOVA with Bonferroni's multiple comparisons post-test was used.

Correlations were examined using Pearson's $r$ and linear regression following runs test to examine deviation from linearity. Significance was considered at two-tailed $P \leq 0.05$.

\section{RESULTS}

\subsection{Bioassay development and characterization}

In general, cell lines with the classical ARE (from ADAMTS1,A) showed higher luciferase activity compared to those transfected with selective AREs (from the TMPRSS2 or PDE9A genes)

(Supplementary Fig. 1A). The colony with highest sensitivity and high induction factors (arrow in Supplementary Fig. 1B; light green line in Fig. S1A) was selected and termed LARA, for Luciferase Androgen $\underline{\text { Reporter }}$ Assay. Fig. 1A shows the luciferase activity in response to various $\mathrm{T}$ concentrations on three representative standard curves. The detection limit for $\mathrm{T}$, defined as the first standard point with luciferase activity more than three standard deviations above vehicle control, was $10^{-9.5} \mathrm{M}(0.3 \mathrm{nM})$ and $\mathrm{EC}_{50}$ was $10^{-7.7} \mathrm{M}(20 \mathrm{nM})$. LARA responded as expected to synthetic androgens, various endogenous androgens as well as to supraphysiological concentrations of E2, progesterone or glucocorticoids (dexamethasone), and not to precursors or metabolites like dehydroepiandrosterone (DHEA) or DHEA-sulphate (DHEAS) (Fig. 1B). These data are in line with the known affinity of these ligands for the AR. Western immunoblot (Fig. 1C) confirmed high AR protein expression in the LARA cell line compared to (i) the AR-negative, ADAMTS1,A-ARE-Lucpositive parental HEK cell line, (ii) the AR-positive VCaP prostate cancer cell line and (iii) a previously established classical ARE (CIARE) cell line designed for compound screening (Helsen et al., 2012) (Fig. 1D). 
A

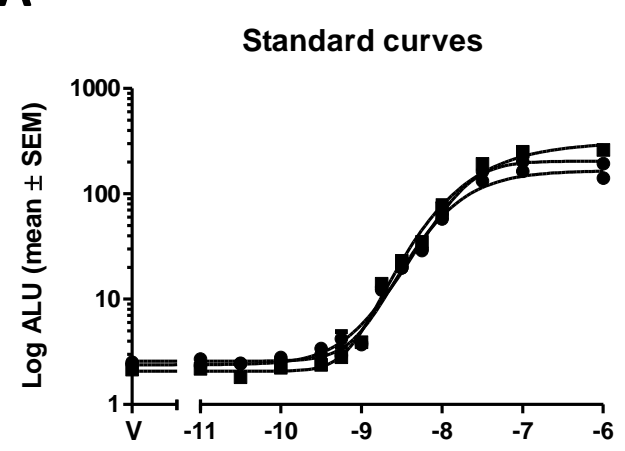

[ T ] $\left(10^{\mathrm{X}} \mathrm{M}\right)$ in $100 \%$ DCC-FCS
B

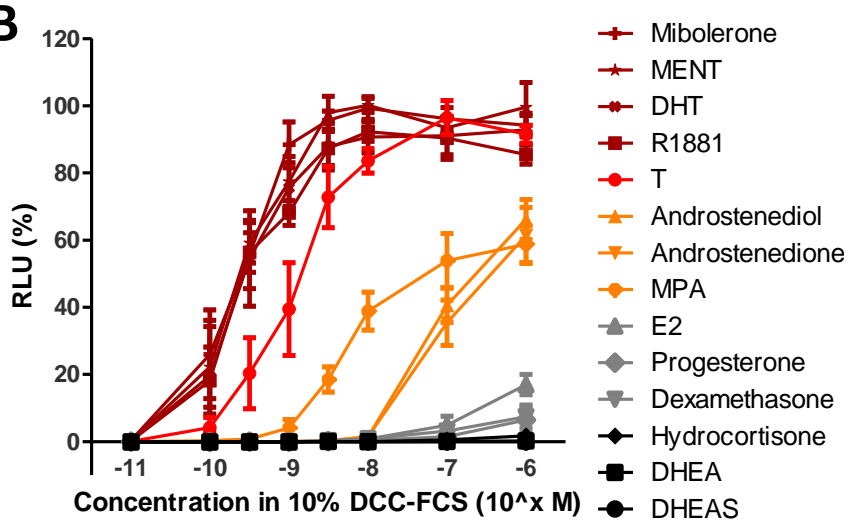

C

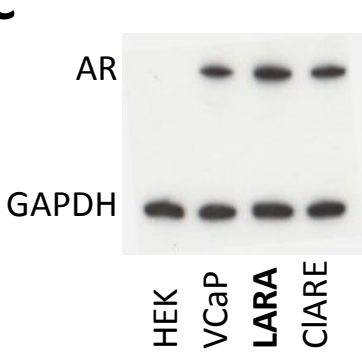

D



Fig. 1. Androgen bioassay characterization.

A. Three representative standard curves showing log-transformed arbitrary luciferase units (ALU) values in response to different T concentrations or vehicle $(V)$ in undiluted DCC-FCS. Means \pm SEM of six replicate wells along with their fitted curve are shown.

B. Luciferase response (relative luciferase units [RLU]) to different hormones ( $n=3$ experiments). As expected, the classical ARE of LARA confers responses not only to natural (T, DHT, as well as Adiol and Adione at supraphysiological concentrations) and synthetic androgens (mibolerone, MENT, R1881 and the weaker medroxyprogesterone acetate, MPA), but also to pharmacological doses of progesterone, dexamethasone and E2.

C. Representative Western blot of whole cell extracts from (i) the parental ADAMTS1,A-ARE-Luc(+), AR(-) HEK cell line, (ii) the VCaP prostate cancer cell line, (iii) LARA cells and (iv) a previous AR bioassay cell line (CIARE) (Helsen et al., 2012).

D. Quantification of protein expression, normalized to GAPDH control and expressed as \% of CIARE values ( $\mathrm{n}=3$ experiments). 


\subsection{Effect of serum dilution on androgen bioassay results and performance}

To test whether serum dilution affected apparent in vitro androgen bioactivity, we prepared 96-well plates with standard curves and samples at different serum concentrations. On each plate, we measured two samples: serum of castrated rats spiked with $10 \mathrm{nM} \mathrm{T}$ and either $1.6 \%$ serum from castrated human SHBG-transgenic mice (=50 nM human SHBG) or $1.6 \%$ serum from castrated WT mice (Jänne et al., 1998). This experimental design takes advantage of the fact that castration not only removes the major source of circulating androgens but also of any SHBG that may leak into the circulation from behind the blood-testis barrier. Indeed, Shbg expression in WT mice and rats is also limited to the testis and not secreted from the liver into the circulation (Gunsalus et al., 1978). The results showed that while in the control condition (without SHBG) the measurements were unaffected by dilution, the apparent androgen bioactivity was significantly increased at $5 \%$ and $10 \%$ serum compared to undiluted serum in an SHBG-dependent fashion (Fig. 2A).

To investigate whether use of undiluted serum was possible, we incubated LARA cells with increasing serum concentrations. Applying 100\% human serum overnight resulted in altered ("bloated") cell morphology compared to 10\% FCS or 10\% human serum (Fig. 2B). Quantitatively however, increasing serum concentrations were not detrimental but rather increased luciferase activity using unspiked human male serum (Fig. 2C). The rising absolute luciferase activity could be attributed to increasing absolute androgen concentrations in less diluted serum, since luciferase activity remained stable when using a pool of serum from prostate cancer patients under androgen deprivation therapy (ADT). Likewise, the background luciferase signal in the parental ADAMTS1,A-ARE-Luc(+), AR(-) cell line remained stable up to $100 \%$ serum (Fig. 2D). Similarly, the number of viable cells as determined by XTT assay was not significantly different between $10 \%$ and $100 \%$ serum (Fig. 2E). However, since cell number is determined by both cell proliferation and cell death, we evaluated these components individually. DNA replication as measured by ${ }^{3} \mathrm{H}$-thymidine incorporation was significantly reduced at higher serum percentages (Fig. 2F). Cytotoxicity as measured with the CellTox ${ }^{\mathrm{TM}}$ Green dye was slightly but significantly higher at $50 \%$ and $80 \%$ (Fig. 2G), but this is probably due to greater cell number. However there was no significant difference between $10 \%$ and $100 \%$ serum, and in any case these differences were marginal compared to the effect of ionomycine as a positive control (Fig. $\mathbf{2 H}$ ). 
A

A SHBG-dependent dilution effect

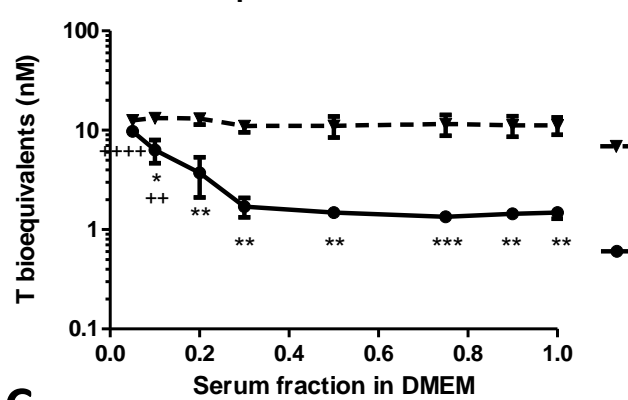

C Luciferase activity (LARA cells)

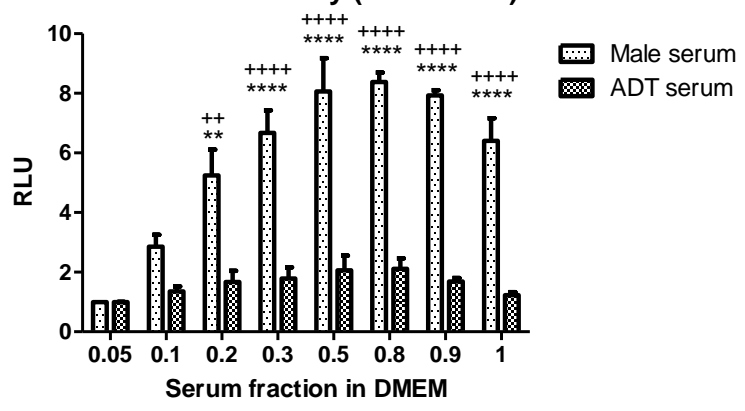

E

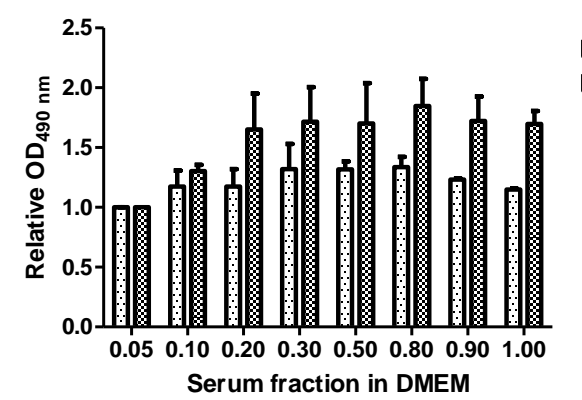

G
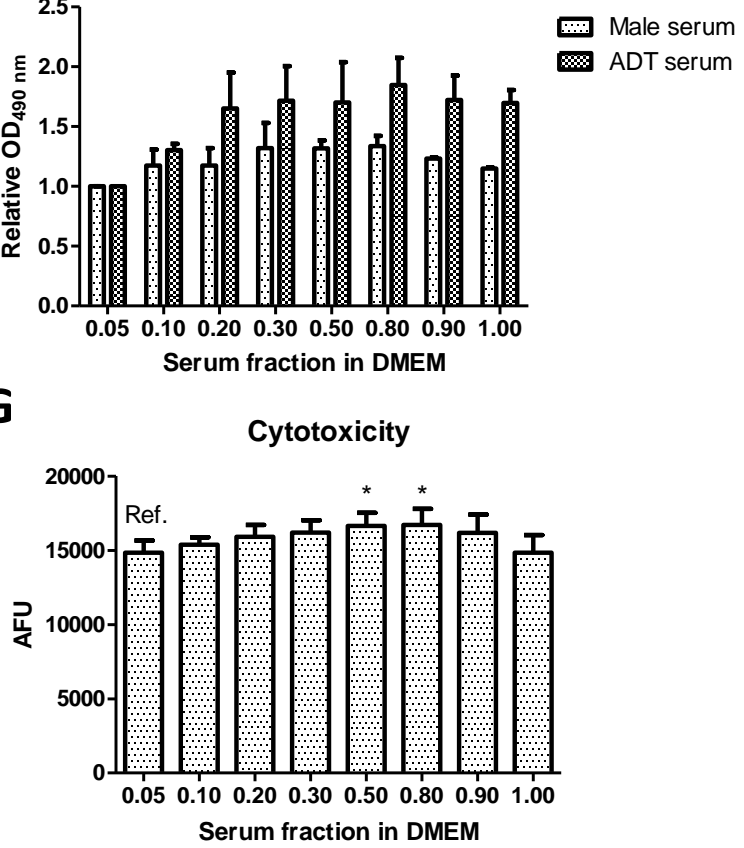

B

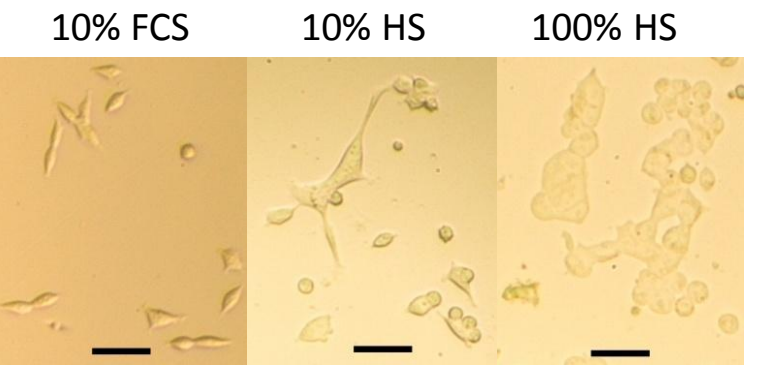

D

Luciferase activity (ARE-Luc+, AR- HEK cells)

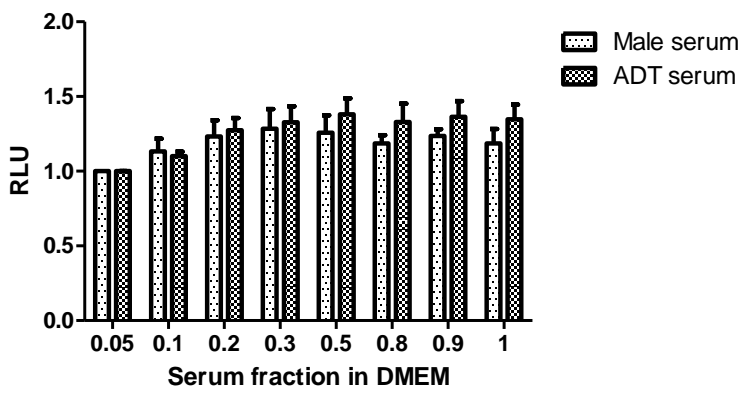

$\mathbf{F}$

Cell proliferation

H
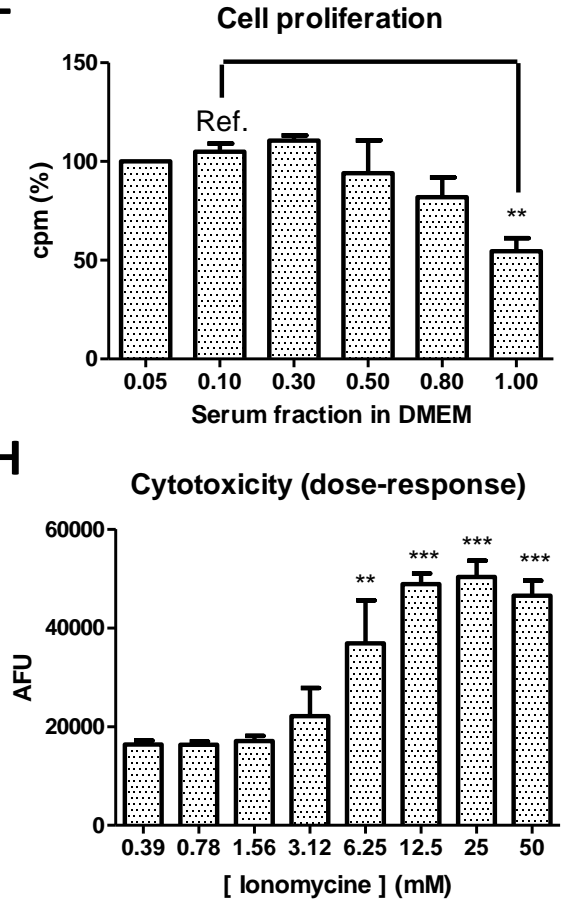

Fig. 2. Effect of serum dilution on in vitro bioassay performance.

A. In the condition without SHBG (dotted curve, triangles), measurements are unaffected by serum sample dilution. In the presence of SHBG (full line, circles), apparent androgen bioactivity is increased at higher dilutions (lower serum fractions: $^{++}=\mathrm{P} \leq 0.01$ and $^{++++}=\mathrm{P} \leq 0.0001$ for $5 \%$ and $10 \%$ serum vs. $100 \%$ serum in the same group, respectively). ${ }^{*}=\mathrm{P} \leq 0.05,{ }^{* *}=\mathrm{P} \leq 0.01,{ }^{* *}=\mathrm{P} \leq 0.001$ for effect of SHBG vs. control at the same dilution (note that at $5 \%$ serum, a significant effect of SHBG can no longer be detected). Analysis by two-way RM ANOVA of $n=3$ experiments, $P<0.0001$ for effect of dilution, $P=0.01$ for effect of $S H B G$ and $P=0.0008$ for interaction. 
B. Representative microphotographs of LARA cells in culture with $10 \%$ FCS, after overnight incubation with $10 \%$ human serum (HS) and with $100 \%$ HS. Bar inset $=0.1 \mathrm{~mm}$.

C. Relative luciferase units (RLU, induction factors) normalized to 5\% serum condition. By two-way RM ANOVA, there was a significant effect of serum dilution $(P<0.0001)$, androgen deprivation $(P=0.02)$ with evidence of interaction $(P<0.0001), n=2$ experiments. Bonferroni post-tests showed ${ }^{\star \star}=P \leq 0.01{ }^{* \star \star \star}=P<0.0001$ for HS vs. ADT serum at the same dilution, $++=P \leq 0.01$, $++++=P<0.0001$ for difference compared to $10 \%$ serum within the same type of serum.

D. Background luciferase activity (shown as RLU i.e. normalized to $5 \%$ serum condition) in the parental AREpositive, AR-negative HEK cell line. No significant differences by two-way RM ANOVA, n=3 experiments.

E. Cell viability (normalized to $5 \%$ serum condition) determined by optical density (OD) at $450 \mathrm{~nm}$ of the colorimetric XTT assay. No significant differences by two-way RM ANOVA, $n=2$ experiments.

F. Thymidine incorporation (expressed as counts per minute, cpm and normalized to 5 serum condition) in response to $16 \mathrm{~h}$ stimulation with various male serum concentrations. ${ }^{* *}=\mathrm{P} \leq 0.01$ by Dunnett's post-test after one-way RM ANOVA (overall $\mathrm{P}=0.002$ ), $\mathrm{n}=3$ experiments.

G. Cytotoxicity as determined by arbitrary fluorescence units (AFU) in the CellTox Green assay in response to increasing human serum sample concentrations. * $=\mathrm{P} \leq 0.05$ by Dunnett's post-test after one-way RM ANOVA (overall $P=0.008), n=3$ experiments.

H. Cytotoxicity in response to increasing ionomycine concentrations. ${ }^{* *}=\mathrm{P} \leq 0.01,{ }^{* *}=\mathrm{P} \leq 0.001$ by Dunnett's post-test after one-way RM ANOVA (overall $\mathrm{P}<0.0001$ ), $\mathrm{n}=3$ experiments.

\subsection{Effect of WT and mutant SHBG on androgen bioactivity in vitro}

To study the effects of human SHBG on in vitro androgen bioactivity in an undiluted serum context, we obtained serum from a recently described SHBG-deficient man, who presented with low total but normal free T serum concentrations (Vos et al., 2014). In vitro androgen bioactivity appeared to be in the low-normal range in this man (Fig. 3A, compare to Fig. 4A-B below) and was significantly decreased by adding recombinant human SHBG.

Several SHBG mutants have been described which display altered affinity constants for T and DHT (Hogeveen et al., 2002, Ohlsson et al., 2011, Wu and Hammond, 2014). We obtained these mutants in concentrated conditioned media from HEK cells transfected with different expression plasmids. Mutant $\mathrm{P} 156 \mathrm{~L}$ was consistently produced at lower levels, therefore a more concentrated matrix was used. However all mutants were recognized similarly by the two clinical immunoassay platforms (data not shown). Western blot using an in-house polyclonal rabbit anti-human SHBG antiserum suggested that 
two mutants (G195E and T48I) were present in the media (Supplementary Fig. 2) despite being present in low to undetectable concentrations using the Roche immunoassay, therefore these two mutants were probably underrecognized by the monoclonal antibody and not analyzed in further experiments. When tested in our bioassay, both SHBG WT and T7N (which has altered glycosylation but normal binding affinity) reduced androgen bioactivity. This reduction was less pronounced when using a mutant that is completely binding deficient (S42L) or a mutant with 4.3-fold lower androgen binding affinity $(\mathrm{R} 123 \mathrm{H})$. No difference could be detected with the R123C or P156L mutants, for which modest alterations in binding affinity have been reported (1.6-fold lower for R123C and 2-fold lower affinity for P156L) (Fig. 3B).

Next, we examined the effect of SHBG on the in vitro androgen bioactivity of different sex steroids alone or in combination at (male) physiological concentrations. For this experiment, we used undiluted serum from orchidectomized rats and orchidectomized SHBG-transgenic or WT male mice spiked with varying hormone concentrations (see Materials and methods). The rationale for this experiment was that different sex steroids have different affinities not only for AR but also for SHBG, and therefore it has been suggested that the balance between different ligands could be altered in the presence of SHBG (i.e. because one ligand competes another off of SHBG, making it more accessible for AR, for example). We found circulating androgen bioactivity to be determined not only by $\mathrm{T}$ but also by $\mathrm{DHT}$, whereas Adiol and Adione or E2 at physiological concentrations had no effect. SHBG significantly reduced the androgen bioactivity of DHT more so than that of $\mathrm{T}$, however with no additional differences or interactions from other endogenous sex steroids (Fig. 3C). Thus, SHBG did not appear to modify the balance between different endogenous sex steroids at male physiological concentrations in a pure serum context in vitro. 
A

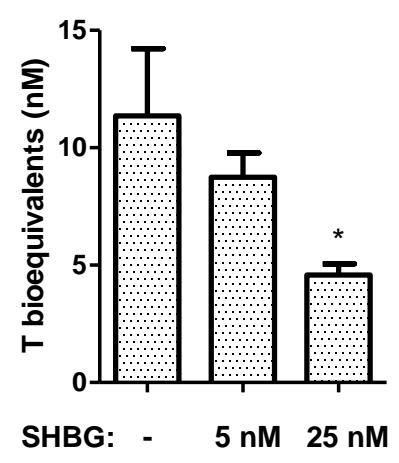

B SHBG-WT and mutants

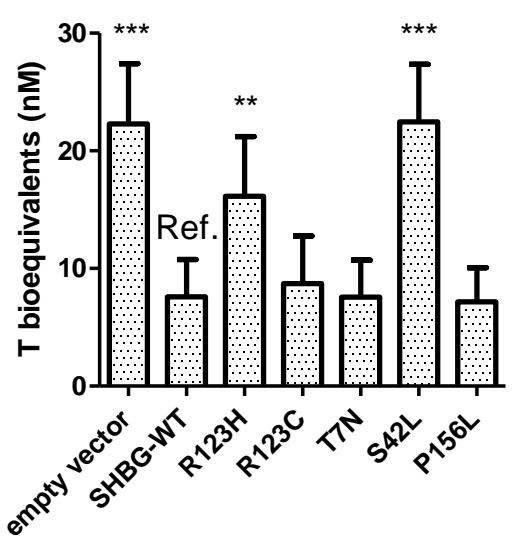

C Androgen bioactivity in vitro

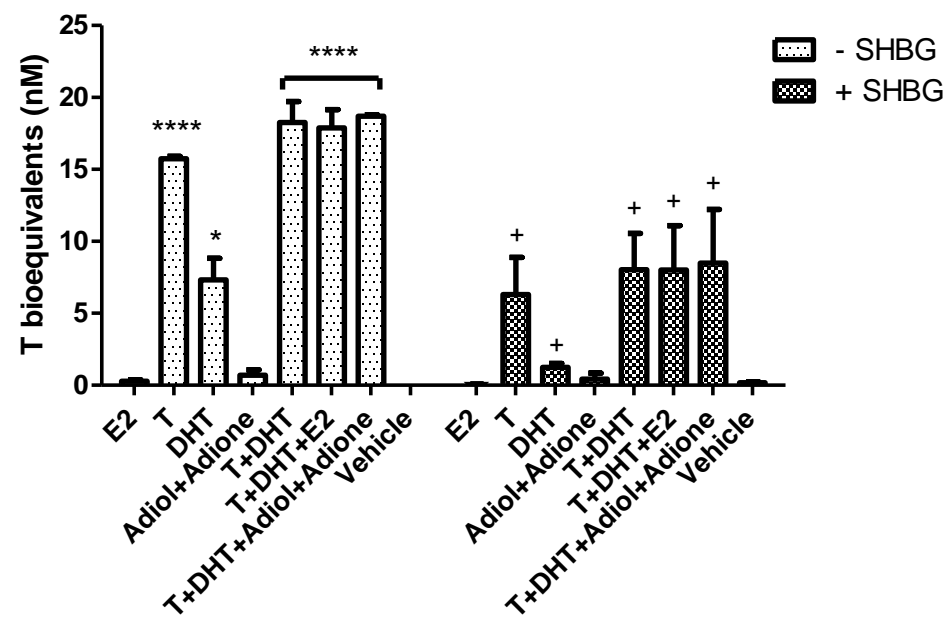

Fig. 3. Effects of SHBG on in vitro androgen bioactivity.

A. In vitro androgen bioactivity in serum from an SHBG-deficient man (Vos et al., 2014), without and with increasing recombinant human SHBG concentrations. ${ }^{*}=\mathrm{P}<0.05$ by Bonferroni post-test after one-way RM ANOVA (overall $\mathrm{P}<0.05), \mathrm{n}=3$ experiments.

B. Effect of recombinant SHBG WT and different mutants on the bioactivity of $20 \mathrm{nM}$ T in DMEM containing $10 \%$ DCC-FCS and conditioned media at various dilutions to obtain $50 \mathrm{nM}$ SHBG final concentration in all conditions. Results adjusted for matrix effects using values after spiking with $R 188110^{-6} \mathrm{M}$. ${ }^{* *}=P \leq 0.01,{ }^{* * *}=P \leq 0.001$ by Dunnett's post-test after one-way RM ANOVA (overall $\mathrm{P}<0.0001$ ), $\mathrm{n}=3$ experiments.

C. Androgen bioactivity expressed as T bioequivalents (in $\mathrm{nM}$ ) in response to physiological male concentrations of E2 $(0.1 \mathrm{nM}), \mathrm{T}(17 \mathrm{nM})$, DHT (1 nM), Adiol and Adione (each $3 \mathrm{nM})$ alone or in combination, and either in the presence or absence of $50 \mathrm{mM}$ recombinant WT human SHBG, in undiluted serum of orchidectomized rats (see Materials and Methods). ${ }^{*}=\mathrm{P} \leq 0.05,{ }^{* * * *}=\mathrm{P}<0.0001$ for significant induction compared to vehicle control in the absence of SHBG, + = P $\leq 0.05$ for effect of SHBG compared to the same hormone group without SHBG. Analysis by two-way RM ANOVA of $n=2$ experiments, $P<0.0001$ for effect of different hormones, $P<0.0001$ for effect of SHBG and $\mathrm{P}=0.02$ for interaction. 


\subsection{Pilot study on androgen bioactivity in hypogonadal men}

Twelve prospectively recruited men (median 47.5 years, range 19-75 years) started androgen deprivation therapy (ADT) for either paraphilias $(n=6)$, hypersexual behavior $(n=3)$ or cross-sex hormone treatment $(n=3)$. Of these 12 patients, 11 started treatment with cyproterone acetate (CPA) 50-100 mg/day (Androcur ${ }^{\circledR}$, an anti-androgen which also decreases gonadotropin concentrations and androgen synthesis via its progestagenic effects). Androgen bioactivity decreased in all of these patients from median $17.5 \mathrm{nM}$ (interquartile range 11.2-30.9) to $1.4 \mathrm{nM}$ (IQR 1.15 - 1.58), and this $>10$-fold reduction was overall significant (Wilcoxon matched-pairs signed rank test, $P=0.001$ ) (Fig. 4A). In comparison, serum T concentrations in these patients only reduced $\sim 4$-fold from median 462.2 ng/dL (IQR, 320.3 - 528.4) to $106.9 \mathrm{ng} / \mathrm{dL}$ (IQR 45.3 - 162.3). One patient with incomplete biochemical response to CPA (serum T $187.7 \mathrm{ng} / \mathrm{dL}$ ) and persistent symptoms despite CPA 150 $\mathrm{mg} /$ day was switched to the gonadoreline analogue triptoreline (Salvacyl®). This reduced his androgen bioactivity from 2.7 to $0.5 \mathrm{nM}$ T bioequivalents.

Twelve other prospectively recruited male hypogonadal patients (median 53.5 years, range 38-77) started androgen replacement therapy with either transdermal or intramuscular T (Androge $\AA^{\circledR}$ or Sustanon ${ }^{\circledR}, \mathrm{n}=6$ each). Serum T concentrations were median $184 \mathrm{ng} / \mathrm{dL}($ IQR $132.6-278)$ at baseline and $316.5 \mathrm{ng} / \mathrm{dL}($ IQR 248.4 - 397.1) at follow-up visit. Compared to the normal male reference range for SHBG (24-55 nmol/L), four men had low and three had high SHBG at baseline or follow-up ( $n=11 / 24$ samples in total). Androgen bioactivity increased in 10/12 patients from a median 5.9 (IQR 4.9-9.8) to 11.8 (IQR 8.0-15.0) nM T bioequivalents (Wilcoxon matched-pairs signed rank test, $P=0.0049)$ (Fig. 4B). Androgen bioactivity in these patients correlated significantly $(P<0.0001)$ with both calculated bioT as well as free T (Fig. 4C-D). In contrast, total T was only moderately associated with bioactivity $\left(\mathrm{R}^{2}=0.29, \mathrm{P}=0.007\right.$ ) (Fig. $4 \mathrm{E}$ ), particularly considering that total $\mathrm{T}$ and bioT were also correlated $\left(\mathrm{P}<0.0001, \mathrm{R}^{2}=0.64\right)$ (not shown). 
A

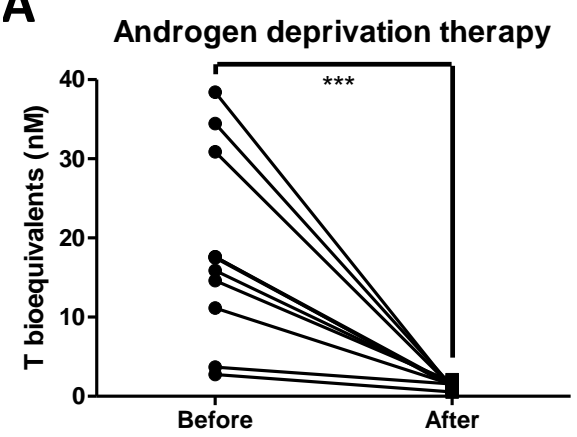

C

C Correlation bioT - bioassay

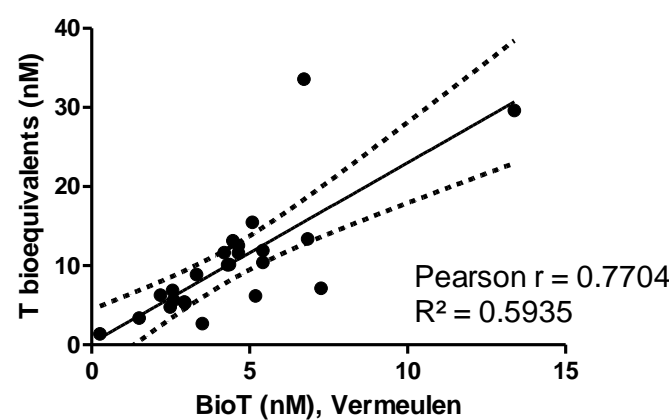

E

Correlation total T - bioassay



B Androgen replacement therapy

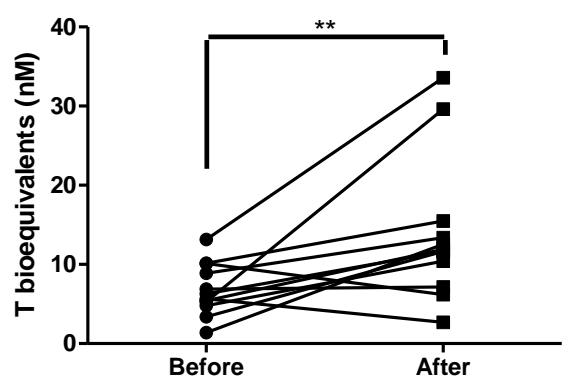

D Correlation free T - bioassay

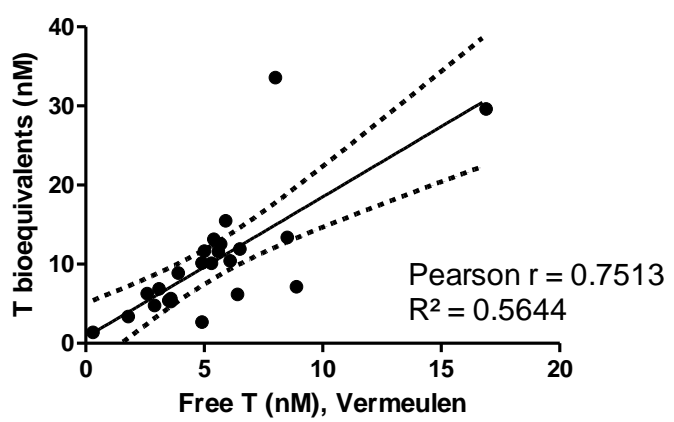

Fig. 4. In vitro androgen bioactivity in hypogonadal men.

A. Androgen bioactivity (expressed as $\mathrm{nM}$ T bioequivalents) in $\mathrm{n}=12$ men before and after androgen deprivation therapy. ${ }^{* * *}=\mathrm{P}=0.001$ by Wilcoxon matched-pairs signed rank test.

B. Androgen bioactivity in $n=12$ men before and after androgen replacement therapy. ${ }^{* *}=P=0.0049$ by Wilcoxon matched-pairs signed rank test.

C-E. Correlation of bioT, free T (calculated according to (Vermeulen et al., 1999)) or total T with in vitro androgen bioactivity in men before and after androgen replacement therapy ( $n=24$ samples in total). The Vermeulen formula for free $\mathrm{T}$ or bioT is based on a linear law of mass action equation assuming a fixed SHBG affinity constant and using as input variables the observed concentrations of total T, SHBG and/or albumin. The 95\% confidence band of the linear regression is shown as a dotted line.

On two different 96-well plates, most patient samples (before or after androgen replacement therapy) spiked with $\mathrm{DHT} 10^{-6} \mathrm{M}$ showed values that were significantly higher than the maximal signal obtained 
with $10^{-6} \mathrm{M}$ T or DHT in DCC-FCS. This can only be explained by matrix effects of serum that were found to be mostly positive matrix effects, i.e. increasing the luciferase signal, except in one sample

\section{(Supplementary Fig. 3).}

\subsection{Pilot study on androgen bioactivity in prostate cancer patients}

Forty-nine prospectively recruited prostate cancer patients (median age 75 years, range 61-87 years) provided serum for analysis. These patients were treated with either androgen deprivation therapy (ADT, $n=24$ of which $n=21$ gonadorelin analogues and $n=3$ gonadorelin antagonists), dual androgen blockade (ADT + bicalutamide, Bic $n=16$ ), androgen synthesis inhibitors (Synth-I: $n=3$ orteronel, $n=2$ abiraterone, $n=1$ ketoconazole; all with add-on glucocorticoids) or Bic monotherapy $(n=2)$, and one was treatment-naive (pre-ADT). Serum total T concentrations measured by LC-MS/MS in different groups are shown in Fig. 5A. Except for one patient, all men treated with ADT or ADT+Bic had serum $\mathrm{T}<50 \mathrm{ng} / \mathrm{dL}$ (and even $<20 \mathrm{ng} / \mathrm{dL}$ ). The proportion of samples with $\mathrm{T}$ concentrations below the LCMS/MS limit of quantification $(<5.0 \mathrm{ng} / \mathrm{dL}$ ) was greater in the Synth-I group $(6 / 6)$ than in the ADT or ADT+Bic groups (3/24 and 1/16 respectively; both $\left.x^{2} P<0.0001\right)$ (Fig. 5A). These results are based on LC-MS/MS because serum T measured by immunoassay showed considerable disagreement between these methods at concentrations $<50 \mathrm{ng} / \mathrm{dL}$ (Fig. 5B). Serum $\mathrm{T}$ was undetectable by immunoassay in 13/24 ADT and 2/16 ADT+Bic patients, but this was confirmed by LC-MS/MS only in 3/13 and 0/2 patients, respectively. Conversely, serum T was below the LC-MS/MS limit of quantification in 3/24 ADT and 1/16 ADT+Bic patient, all of which were confirmed by immunoassay.

We compared the ADT and Synth-I groups ( $n=2$ were excluded from the ADT group due to insufficient remaining serum) in the bioassay, in the absence or presence of the potent anti-androgen enzalutamide. Neither the total luciferase values in the vehicle condition nor the values following enzalutamide suppression were significantly different between the two groups (data not shown). However, spiking with enzalutamide resulted in a significant signal suppression ( $\Delta$ suppression, defined as the total luciferase activity with vehicle minus values after enzalutamide suppression i.e. how much the signal can be suppressed by a potent AR antagonist) in 17/23 ADT patients vs. 0/6 Synth-I patients $\left(X^{2} P=0.001\right)$ (Fig. 5 C). We reasoned that the total luciferase activity (without enzalutamide) consists on the one hand of the $\Delta$ suppression (the amount of decrease in the luciferase signal due to enzalutamide) which represents the true AR bioactivity in patients with very low androgen levels, whereas the remaining luciferase activity after enzalutamide suppression is 
determined by other (matrix) effects. In other words, total serum luciferase activity $=\Delta$ suppression (or androgen effect) + background signal (or matrix effect). This was supported by two elements. Firstly, serum T concentrations were significantly lower in ADT patients without $(n=6)$ vs. with significant further $\Delta$ suppression ( $n=16, P=0.04$ by Mann-Whitney test) (Fig. 5D), indicating that $\Delta$ suppression represents the true residual androgen bioactivity in these patients. Importantly, the bioactivity in $2 / 3$ ADT patients with serum T below the LC-MS/MS limit of quantification could still be further suppressed by enzalutamide (vs. 0/6 with Synth-I, $X^{2} P=0.02$ ), suggesting that androgen bioactivity may not always be completely suppressed in ADT patients with undetectable total T concentrations. Along the same lines, $\Delta$ suppression correlated significantly (although weakly) with calculated free $T$ and bioT $\left(R^{2}=\right.$ 0.48 and 0.47 respectively, both $\mathrm{P}<0.0001$ ) (Fig. 5E, F). Serum total T levels also correlated significantly with $\Delta$ suppression $\left(R^{2}=0.42, P=0.0001\right)$, although only weakly with total luciferase values $\left(R^{2}=0.25, P=0.005\right)$ and not with enzalutamide-suppressed ("baseline") values (data not shown). Thus, our hypothesis that the androgen bioactivity in these samples could be gauged from $\Delta$ suppression was supported. Secondly, there was a good correlation $\left(P<0.0001, R^{2}=0.66\right)$ between total luciferase readings without enzalutamide and the $\Delta$ suppression (Fig. 5G). This graph allows identification of samples with below (pat. 15) or above average (pat. 11, 23 and 45) readouts in Fig. 5B (i.e. samples with negative or positive matrix effects). 
A

Serum total T (LC-MS/MS)

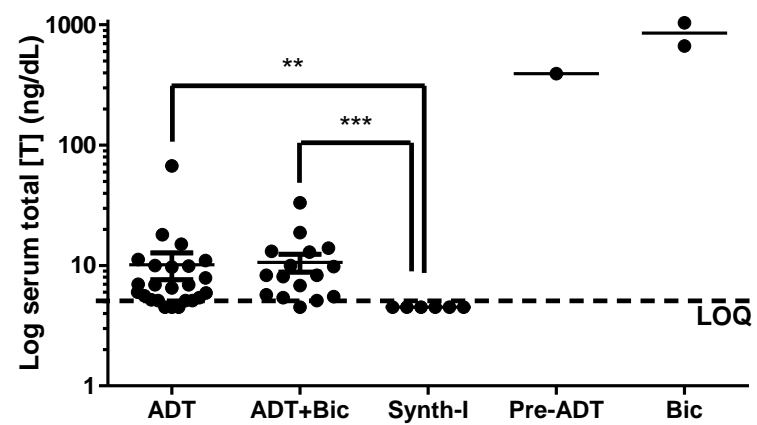

C

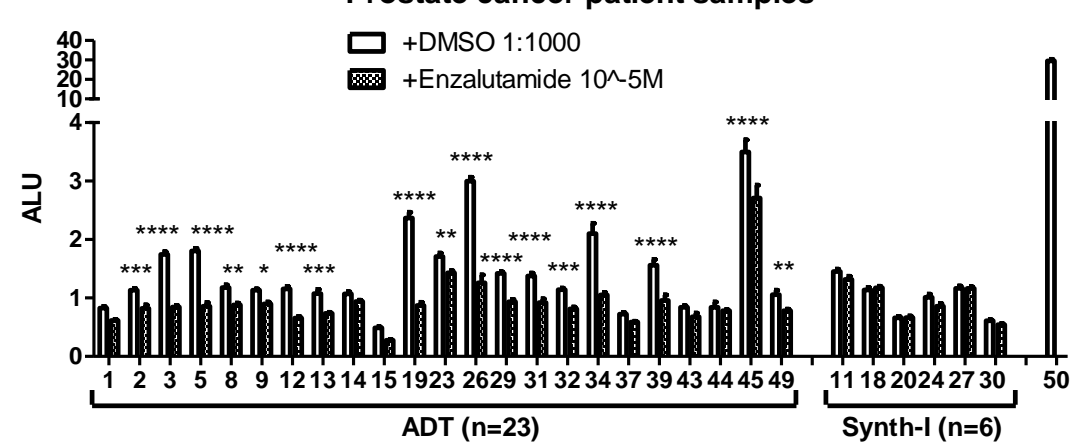

B



D Androgen bioactivity in ADT

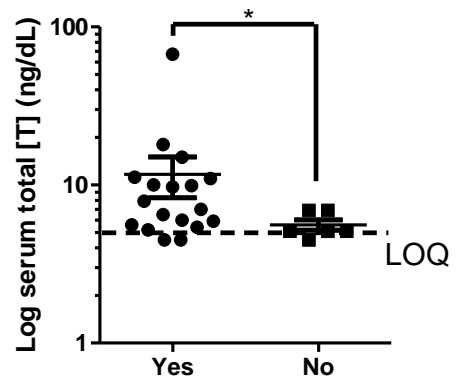

Significant residual AR bioactivity?

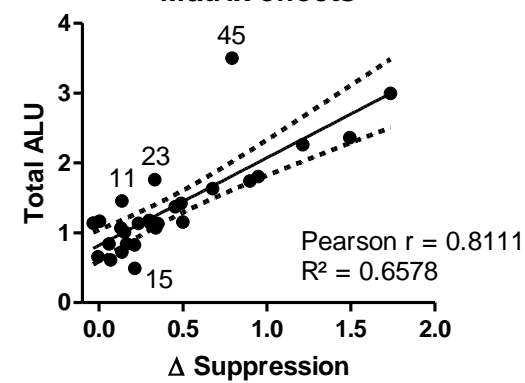

Matrix effects

$\mathbf{G}$

Suppression
E Correlation biot - bioassay

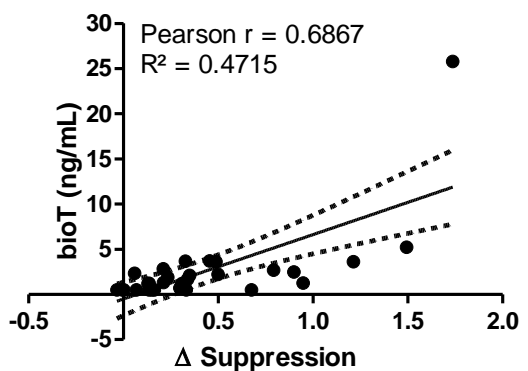

F Correlation free T - bioassay



Fig. 5. Pilot study on androgen bioactivity in prostate cancer patients.

A. Serum total T concentrations in different treatment groups. The LC-MS/MS limit of quantification (LOQ) (5 $\mathrm{ng} / \mathrm{dL})$ is indicated by the horizontal dotted line. Individual values are plotted along with mean \pm SEM values. ${ }^{* *}=$ $\mathrm{P} \leq 0.01,{ }^{* * *}=\mathrm{P} \leq 0.001$ by Dunn's multiple comparisons test (after Kruskal-Wallis test, overall $\mathrm{P} \leq 0.001$ ).

B. Bland-Altman methods comparison showing relative deviation (in \%) of serum total T measurements by immunoassay plotted against the average of LC-MS/MS and immunoassay results. The LC-MS/MS LOQ is indicated by the vertical dotted line.

C. Arbitrary luciferase unit (ALU) values of ADT or Synth-I treatment groups. Pre-ADT patient sample (nr. 50) shown for reference. ${ }^{*}=\mathrm{P} \leq 0.05,{ }^{* *}=\mathrm{P} \leq 0.01,{ }^{* * *}=\mathrm{P} \leq 0.001,{ }^{* * * *}=\mathrm{P}<0.0001$ for each sample with $10^{-5} \mathrm{M}$ enzalutamide compared to its vehicle-spiked control. Analysis by two-way RM ANOVA with differences between samples, effect of enzalutamide as well as interaction effect all $\mathrm{P} \leq 0.0001$.

D..T serum concentrations in ADT patients with $(n=17)$ or without $(n=6)$ significant residual androgen bioactivity as shown in panel $C\left(n=23\right.$ ADT patients in total). ${ }^{*}=P=0.04$ by Mann-Whitney test. 
E, F. Correlation of bioT and free $\mathrm{T}$ with $\Delta$ suppression. The $95 \%$ confidence band of the linear regression is shown as a dotted line.

G. Correlation of total ALU values with $\Delta$ suppression. The $95 \%$ confidence band of the linear regression is shown as a dotted line, and significant outlier samples are identified by number (compare with panel C).

\section{DISCUSSION}

Several in vitro androgen bioassays have been previously established and applied to analyze serum from older men (Need et al., 2010, Raivio et al., 2002), women (Chen et al., 2006), children (Paris et al., 2002b, Raivio et al., 2001, Raivio et al., 2004), hyperandrogenic women or children (Hero et al., 2005, Liimatta et al., 2014, Roy et al., 2006) or prostate cancer patients (Raivio et al., 2003, Rannikko et al., 2006), for example. In our hands, optimal assay characteristics were achieved using full-length human AR (Christiaens et al., 2005) and a classical ARE (Suppl. Fig. 1) (Denayer et al., 2010). The specificity of our cell line (Fig. 1B) was in line with previous cell lines using classical AREs, although most others have reported better sensitivity (Blankvoort et al., 2001, Chen et al., 2006, Paris et al., 2002b, Raivio et al., 2001, Roy et al., 2004, Roy et al., 2006, Sonneveld et al., 2005, Terouanne et al., 2000). However, this may be due to the use of steroid extraction procedures as well as serum dilution in other assays, given that others who have used undiluted serum have reported a sensitivity similar to ours (Need et al., 2010). Another group recently reported a selective ARE-based system with sensitivity similar to what we report here (Campana et al., 2016). Since classical AREs have greatest significance in vivo (Schauwaers et al., 2007), we do not consider selective AREs a prerequisite for "specific" androgen bioassays (Campana et al., 2015). In our view, the advantage of bioassays is their broad-spectrum ability to provide an integrated readout of AR agonist and antagonist activity without a priori knowledge of their structure, unlike other methods e.g. mass spectrometry which are already highly sensitive and specific.

Our main finding was that SHBG directly suppresses androgen bioactivity and correlated well with bioavailable or free T concentrations (Fig. 3, Fig. 4). Importantly however, the effect of SHBG on in vitro AR bioactivity was no longer maintained when serum was diluted more than tenfold (Fig. 2A), whereas most previous AR bioassays have used 1-10\% serum conditions. It is known that dilution influences the equilibrium between SHBG and T in other types of assays e.g. in equilibrium dialysis (Van Uytfanghe et al., 2004), and our findings are remarkably similar. One previous study also used undiluted serum (Need et al., 2010) although incubation of cells with serum was limited to only five 
minutes. Our findings show that a HEK293 cell-based assay as previously used by others (Chen et al., 2006, Roy et al., 2006, Wilkinson et al., 2008) offers the advantage of not only lacking significant endogenous steroid metabolism, but also being quite robust and able to withstand overnight incubation in 100\% serum with minimal effects on luciferase activity, cell viability or cytotoxicity (Fig. 2 C-E, G-H). Only proliferation was significantly reduced at $100 \%$ compared to $10 \%$ serum conditions (Fig. 2F), which may in fact be considered beneficial for a transcription-based reporter (rather than a proliferation) bioassay.

A trade-off of using undiluted serum may be an increased likelihood of matrix effects, although these have also been noted in previous studies. To circumvent this problem, (Roy et al., 2006) used diethyl ether extraction whereas (Paris et al., 2002a) compared samples to patient-specific standard curves in steroid-depleted serum. However, either approach likely removes the influence of SHBG, which is a crucial determinant of inter-individual differences in circulating androgen bioactivity. We observed that spiking with either $10^{-5} \mathrm{M}$ of the potent anti-androgen enzalutamide or $10^{-6} \mathrm{M}$ of DHT or R1881 resulted in respectively minimal and maximal luciferase values which differed between different human serum samples as well as between human serum samples and DCC-FCS (Fig. 5C, Suppl. Fig. 3). We made use of these differences to adjust for such matrix effects mathematically, similar to what is commonly used in dual-luciferase assays or when adjusting for transfection efficiency in transient transfection assays.

Although AR bioassays are unlikely to become sufficiently standardized to play a role in routine clinical chemistry (Rosner, 2001), they may offer physiologically useful insights in research settings. Their primary niche is, in our opinion, any situations in which serum $\mathrm{T}$ concentrations alone may be unreliable to assess androgen status, e.g. to detect abuse of synthetic androgens (Fig. 1B) (Cadwallader et al., 2011, Cooper et al., 2013). Another example is DHT treatment in elderly men, which reduces serum T levels but clearly increases androgen bioactivity (Raivio et al., 2002). Patients with altered SHBG concentrations or binding affinities may represent a similar challenging circumstance in which serum total T levels may be misleading (Keevil et al., 2016, Ohlsson et al., 2011). Analysis of serum from a recently described SHBG-deficient man (Vos et al., 2014) with low total T but low-normal free T (Wu et al., 2010) showed in vitro androgen bioactivity in the low-normal range (Fig. 3A, compared to Fig. 4A-B) although our pilot studies are underpowered to formally establish normal reference values for our assay. As expected, we found that AR bioactivity correlated 
more with bioT or free $T$ than with total $T$ in men with variable SHBG concentrations (Fig. 4C-E). A similar degree of correlation with free $T$ has been observed with other measurements like salivary $T$ (Fiers et al., 2014, Keevil et al., 2014). Furthermore, bioactivity in our assay was less suppressed by SHBG mutants with severely reduced $(\mathrm{R} 123 \mathrm{H})$ or completely absent androgen binding (S42L) (Hong et al., 2011, Ohlsson et al., 2011, Wu and Hammond, 2014), although bioassays may not be sensitive enough to detect subtle differences from SHBG mutants like P156L, which increased free $\mathrm{T}$ by $22 \%$ in one study (Ohlsson et al., 2011).

Importantly, our study found a significant but only very modest correlation between AR bioassay results and calculated free $\mathrm{T}$ or bioT results, similar to what others have reported previously using other formulas e.g. the free androgen index (Liimatta et al., 2014). Thus, although SHBG decreases free T concentrations in vitro (Van Uytfanghe et al., Clin Chem 2004) and we now show the same for AR bioassays, this should by no means be taken to imply that AR bioassays are measuring free $T$ concentrations or correlate well with free T measurements. In fact our data confirm previous findings that the correlation between bioassay results and calculated free $\mathrm{T}$ or bioT is quite poor. Although different formulas or direct measurements may have limitations in terms of accurately reflecting free $T$ concentrations, the main reason for this poor correlation with bioassays is probably that AR bioassays are measuring a very different, multifactorial signal which cannot simply be compared to free $T$ concentrations. There are growing concerns surrounding the way free $\mathrm{T}$ is currently applied in clinical practice (Bhasin, 2016, Laurent and Vanderschueren, 2014, Zakharov et al., 2015). Efforts are ongoing to resolve the unmet clinical need of adequate determinations or formulas for free $T$ concentrations but until there is consensus on this issue, the relationship between golden standard free or bioT concentrations and bioassay results cannot be investigated further.

AR bioassays may also be useful to assess androgen status in patients taking anti-androgens. A well known effect of anti-androgens is that they increase serum $T$ concentrations via hypothalamic feedback, even though they reduce net androgen bioactivity. This caveat may apply particularly to patients taking CPA, which has both anti-androgenic, anti-gonadotropic and progestagenic effects. In line with this hypothesis, we found that androgen bioactivity is indeed more reduced than serum T levels in CPA-treated men (Fig. 4A). Perhaps more importantly, we found residual androgen bioactivity in prostate cancer patients receiving ADT (Fig. 5C) but not Synth-I treatment. Previous studies have shown the importance of incompletely suppressed T serum concentrations during ADT, 
although there is some debate whether concentrations $<50,32$ or $20 \mathrm{ng} / \mathrm{dL}$ are optimal (Morote et al., 2007, Morote et al., 2016, van der Sluis et al., 2012a, van der Sluis et al., 2012b). Except for one patient, all men receiving ADT or ADT+Bic in our sample had serum T concentrations $<20 \mathrm{ng} / \mathrm{dL}$, whereas concentrations $<50 \mathrm{ng} / \mathrm{dL}$ are already conventionally considered "castrate" levels. In contrast, all six patients receiving Synth-I treatment had undetectable serum T concentrations. Moreover, these novel agents not only reduce circulating androgen concentrations more completely, but also interfere with intratumoral androgen metabolism. Based on our pilot findings, we suggest further research to investigate whether residual circulating androgen bioactivity during ADT contributes to the development of castration-resistant prostate cancer and/or may be amenable or predictive of response to treatment with novel androgen synthesis inhibitors. However, it should be noted that bioassays can only assess circulating bioactivity which does not necessarily reflect androgen bioactivity within tissues.

In summary, in vitro androgen reporter bioassays are useful tools to study how androgen bioactivity in serum is determined not only by androgens and anti-androgens but also by SHBG. Furthermore, we show that excessive serum dilution decreases the suppressive effect of SHBG on androgen bioactivity and that appropriate attention should also be paid to matrix effects. Importantly, we found differences in residual androgen bioactivity in prostate cancer patients under treatment with ADT or Synth-I. The clinical significance of these findings need further investigation.

\section{CONFLICT OF INTEREST}

The authors declare that they have no conflict of interest.

\section{ACKNOWLEDGEMENTS}

We thank H. De Bruyn, I. Jans, E. Van Herck, G. Saelens, R. Bollen and L. Deboel for excellent technical assistance, and E. Goossens, C. D'Haemer, H. Morobé, S. Achten, R. Van Heyste, C. Hulsbosch, H. Van Poppel, T. Devos and the Departments of Urology and Haematology for help with patient recruitment.

This work was supported by the Research Foundation Flanders (FWO grant G085413N) and grant GOA/15/017 from the KU Leuven Research Council. MRL is supported by a PhD Fellowship from the Research Foundation Flanders. 


\section{REFERENCES}

Avvakumov, G.V., Cherkasov, A., Muller, Y.A. and Hammond, G.L. 2010 Structural analyses of sex hormone-binding globulin reveal novel ligands and function. Mol Cell Endocrinol 316, 13-23.

Bailey, K., Yazdi, T., Masharani, U., Tyrrell, B., Butch, A. and Schaufele, F. 2016 Advantages and Limitations of Androgen Receptor-Based Methods for Detecting Anabolic Androgenic Steroid Abuse as Performance Enhancing Drugs. PLoS One 11, e0151860.

Bhasin, S. 2016 A Perspective on the Evolving Landscape in Male Reproductive Medicine. J Clin Endocrinol Metab 101, 827-36.

Blankvoort, B.M., de Groene, E.M., van Meeteren-Kreikamp, A.P., Witkamp, R.F., Rodenburg, R.J. and Aarts, J.M. 2001 Development of an androgen reporter gene assay (AR-LUX) utilizing a human cell line with an endogenously regulated androgen receptor. Anal Biochem 298, 93102.

Cadwallader, A.B., Lim, C.S., Rollins, D.E. and Botre, F. 2011 The androgen receptor and its use in biological assays: looking toward effect-based testing and its applications. J Anal Toxicol 35, 594-607.

Campana, C., Pezzi, V. and Rainey, W.E. 2015 Cell-based assays for screening androgen receptor ligands. Semin Reprod Med 33, 225-34.

Campana, C., Rege, J., Turcu, A.F., Pezzi, V., Gomez-Sanchez, C.E., Robins, D.M. and Rainey, W.E. 2016 Development of a novel cell based androgen screening model. J Steroid Biochem Mol Biol 156, 17-22.

Chen, J., Sowers, M.R., Moran, F.M., McConnell, D.S., Gee, N.A., Greendale, G.A., Whitehead, C., Kasim-Karakas, S.E. and Lasley, B.L. 2006 Circulating bioactive androgens in midlife women. J Clin Endocrinol Metab 91, 4387-94.

Christiaens, V., Berckmans, P., Haelens, A., Witters, H. and Claessens, F. 2005 Comparison of different androgen bioassays in the screening for environmental (anti)androgenic activity. Environ Toxicol Chem 24, 2646-56.

Clinckemalie, L., Vanderschueren, D., Boonen, S. and Claessens, F. 2012 The hinge region in androgen receptor control. Mol Cell Endocrinol 358, 1-8.

Cooper, E.R., McGrath, K.C. and Heather, A.K. 2013 In vitro androgen bioassays as a detection method for designer androgens. Sensors (Basel) 13, 2148-63. 
De Bruyn, R., Bollen, R. and Claessens, F. 2011 Identification and characterization of androgen response elements. Methods Mol Biol 776, 81-93.

Denayer, S., Helsen, C., Thorrez, L., Haelens, A. and Claessens, F. 2010 The rules of DNA recognition by the androgen receptor. Mol Endocrinol 24, 898-913.

Dunn, J.F., Nisula, B.C. and Rodbard, D. 1981 Transport of steroid hormones: binding of 21 endogenous steroids to both testosterone-binding globulin and corticosteroid-binding globulin in human plasma. J Clin Endocrinol Metab 53, 58-68.

Fiers, T., Delanghe, J., T'Sjoen, G., Van Caenegem, E., Wierckx, K. and Kaufman, J.M. 2014 A critical evaluation of salivary testosterone as a method for the assessment of serum testosterone. Steroids $86,5-9$.

Gunsalus, G.L., Musto, N.A. and Bardin, W. 1978 Immunoassay of androgen binding protein in blood: a new approach for study of the seminiferous tubule. Science $200,65-6$.

Haelens, A., Verrijdt, G., Callewaert, L., Peeters, B., Rombauts, W. and Claessens, F. 2001 Androgenreceptor-specific DNA binding to an element in the first exon of the human secretory component gene. Biochem J 353, 611-20.

Hammond, G.L., Wu, T.S. and Simard, M. 2012 Evolving utility of sex hormone-binding globulin measurements in clinical medicine. Curr Opin Endocrinol Diabetes Obes 19, 183-9.

Heinrich-Balard, L., Zeinyeh, W., Dechaud, H., Rivory, P., Roux, A., Pugeat, M. and Cohen, R. 2015 Inverse relationship between hSHBG affinity for testosterone and hSHBG concentration revealed by surface plasmon resonance. Mol Cell Endocrinol 399, 201-7.

Helsen, C., Marchand, A., Chaltin, P., Munck, S., Voet, A., Verstuyf, A. and Claessens, F. 2012 Identification and characterization of MEL-3, a novel AR antagonist that suppresses prostate cancer cell growth. Mol Cancer Ther 11, 1257-68.

Helsen, C. and Claessens, F. 2014 Looking at nuclear receptors from a new angle. Mol Cell Endocrinol 382, 97-106.

Hero, M., Jänne, O.A., Nanto-Salonen, K., Dunkel, L. and Raivio, T. 2005 Circulating antiandrogenic activity in children with congenital adrenal hyperplasia during peroral flutamide treatment. $\mathrm{J}$ Clin Endocrinol Metab 90, 5141-5. 
Hogeveen, K.N., Cousin, P., Pugeat, M., Dewailly, D., Soudan, B. and Hammond, G.L. 2002 Human sex hormone-binding globulin variants associated with hyperandrogenism and ovarian dysfunction. J Clin Invest 109, 973-81.

Hong, E.J., Sahu, B., Jänne, O.A. and Hammond, G.L. 2011 Cytoplasmic accumulation of incompletely glycosylated SHBG enhances androgen action in proximal tubule epithelial cells. Mol Endocrinol 25, 269-81.

Jänne, M., Deol, H.K., Power, S.G., Yee, S.P. and Hammond, G.L. 1998 Human sex hormone-binding globulin gene expression in transgenic mice. Mol Endocrinol 12, 123-36.

Keevil, B.G., MacDonald, P., Macdowall, W., Lee, D.M. and Wu, F.C. 2014 Salivary testosterone measurement by liquid chromatography tandem mass spectrometry in adult males and females. Ann Clin Biochem 51, 368-78.

Keevil, B.G., Fiers, T., Kaufman, J.M., Macdowall, W., Clifton, S., Lee, D. and Wu, F. 2016 Sex hormone-binding globulin has no effect on salivary testosterone. Ann Clin Biochem.

Kerkhofs, S., Dubois, V., De Gendt, K., Helsen, C., Clinckemalie, L., Spans, L., Schuit, F., Boonen, S., Vanderschueren, D., Saunders, P.T., Verhoeven, G. and Claessens, F. 2012 A role for selective androgen response elements in the development of the epididymis and the androgen control of the 5alpha reductase II gene. FASEB J 26, 4360-72.

Laurent, M.R. and Vanderschueren, D. 2014 Reproductive endocrinology: Functional effects of sex hormone-binding globulin variants. Nat Rev Endocrinol.

Liimatta, J., Laakso, S., Utriainen, P., Voutilainen, R., Palvimo, J.J., Jääskeläinen, T. and Jääskeläinen, J. 2014 Serum androgen bioactivity is low in children with premature adrenarche. Pediatr Res 75, 645-50.

Marivoet, S., Hertogen, M., Verhoeven, G. and Heyns, W. 1990 Antibodies against synthetic peptides recognize the human and rat androgen receptor. J Steroid Biochem Mol Biol 37, 39-45.

Marty, M.S. and O'Connor, J.C. 2014 Key learnings from the Endocrine Disruptor Screening Program (EDSP) Tier 1 rodent uterotrophic and Hershberger assays. Birth Defects Res B Dev Reprod Toxicol 101, 63-79.

Mendel, C.M. 1989 The free hormone hypothesis: a physiologically based mathematical model. Endocr Rev 10, 232-74. 
Morote, J., Orsola, A., Planas, J., Trilla, E., Raventos, C.X., Cecchini, L. and Catalan, R. 2007 Redefining clinically significant castration levels in patients with prostate cancer receiving continuous androgen deprivation therapy. J Urol 178, 1290-5.

Morote, J., Regis, L., Celma, A. and Planas, J. 2016 Measurement of serum testosterone during androgenic suppression in patients with prostate cancer: A systematic review. Actas Urol Esp.

Munzker, J., Hofer, D., Trummer, C., Ulbing, M., Harger, A., Pieber, T., Owen, L., Keevil, B., Brabant, G., Lerchbaum, E. and Obermayer-Pietsch, B. 2015 Testosterone to dihydrotestosterone ratio as a new biomarker for an adverse metabolic phenotype in the polycystic ovary syndrome. $\mathrm{J}$ Clin Endocrinol Metab 100, 653-60.

Need, E.F., O'Loughlin, P.D., Armstrong, D.T., Haren, M.T., Martin, S.A., Tilley, W.D., Wittert, G.A. and Buchanan, G. 2010 Serum testosterone bioassay evaluation in a large male cohort. Clin Endocrinol (Oxf) 72, 87-98.

O'Reilly, M.W., Taylor, A.E., Crabtree, N.J., Hughes, B.A., Capper, F., Crowley, R.K., Stewart, P.M., Tomlinson, J.W. and Arlt, W. 2014 Hyperandrogenemia predicts metabolic phenotype in polycystic ovary syndrome: the utility of serum androstenedione. J Clin Endocrinol Metab 99, 1027-36.

Ohlsson, C., Wallaschofski, H., Lunetta, K.L., Stolk, L., Perry, J.R., Koster, A., Petersen, A.K., Eriksson, J., Lehtimaki, T., Huhtaniemi, I.T., Hammond, G.L., Maggio, M., Coviello, A.D., Ferrucci, L., Heier, M., Hofman, A., Holliday, K.L., Jansson, J.O., Kahonen, M., Karasik, D., Karlsson, M.K., Kiel, D.P., Liu, Y., Ljunggren, O., Lorentzon, M., Lyytikainen, L.P., Meitinger, T., Mellstrom, D., Melzer, D., Miljkovic, I., Nauck, M., Nilsson, M., Penninx, B., Pye, S.R., Vasan, R.S., Reincke, M., Rivadeneira, F., Tajar, A., Teumer, A., Uitterlinden, A.G., Ulloor, J., Viikari, J., Volker, U., Volzke, H., Wichmann, H.E., Wu, T.S., Zhuang, W.V., Ziv, E., Wu, F.C., Raitakari, O., Eriksson, A., Bidlingmaier, M., Harris, T.B., Murray, A., de Jong, F.H., Murabito, J.M., Bhasin, S., Vandenput, L. and Haring, R. 2011 Genetic determinants of serum testosterone concentrations in men. PLoS Genet 7, e1002313.

Paris, F., Servant, N., Terouanne, B., Balaguer, P., Nicolas, J.C. and Sultan, C. 2002a A new recombinant cell bioassay for ultrasensitive determination of serum estrogenic bioactivity in children. J Clin Endocrinol Metab 87, 791-7. 
Paris, F., Servant, N., Terouanne, B. and Sultan, C. 2002b Evaluation of androgenic bioactivity in human serum by recombinant cell line: preliminary results. Mol Cell Endocrinol 198, 123-9.

Pihlajamaa, P., Sahu, B. and Jänne, O.A. 2015 Determinants of Receptor- and Tissue-Specific Actions in Androgen Signaling. Endocr Rev 36, 357-84.

Raivio, T., Palvimo, J.J., Dunkel, L., Wickman, S. and Jänne, O.A. 2001 Novel assay for determination of androgen bioactivity in human serum. J Clin Endocrinol Metab 86, 1539-44.

Raivio, T., Tapanainen, J.S., Kunelius, P. and Jänne, O.A. 2002 Serum androgen bioactivity during 5alpha-dihydrotestosterone treatment in elderly men. J Androl 23, 919-21.

Raivio, T., Santti, H., Schatzl, G., Gsur, A., Haidinger, G., Palvimo, J.J., Jänne, O.A. and Madersbacher, S. 2003 Reduced circulating androgen bioactivity in patients with prostate cancer. Prostate 55, 194-8.

Raivio, T., Dunkel, L., Wickman, S. and Jänne, O.A. 2004 Serum androgen bioactivity in adolescence: a longitudinal study of boys with constitutional delay of puberty. J Clin Endocrinol Metab 89, $1188-92$

Rannikko, A., Petas, A., Raivio, T., Jänne, O.A., Rannikko, S. and Adlercreutz, H. 2006 The effects of short-term oral phytoestrogen supplementation on the hypothalamic-pituitary-testicular axis in prostate cancer patients. Prostate 66, 1086-91.

Rosner, W. 2001 La plus ça change, la plus c'est la même chose--will bioassays make a comeback? J Clin Endocrinol Metab 86, 1898-9.

Rosner, W., Auchus, R.J., Azziz, R., Sluss, P.M. and Raff, H. 2007 Position statement: Utility, limitations, and pitfalls in measuring testosterone: an Endocrine Society position statement. J Clin Endocrinol Metab 92, 405-13.

Rosner, W., Hankinson, S.E., Sluss, P.M., Vesper, H.W. and Wierman, M.E. 2013 Challenges to the measurement of estradiol: an endocrine society position statement. J Clin Endocrinol Metab $98,1376-87$.

Roy, P., Salminen, H., Koskimies, P., Simola, J., Smeds, A., Saukko, P. and Huhtaniemi, I.T. 2004 Screening of some anti-androgenic endocrine disruptors using a recombinant cell-based in vitro bioassay. J Steroid Biochem Mol Biol 88, 157-66. 
Roy, P., Franks, S., Read, M. and Huhtaniemi, I.T. 2006 Determination of androgen bioactivity in human serum samples using a recombinant cell based in vitro bioassay. J Steroid Biochem Mol Biol 101, 68-77.

Roy, P., Alevizaki, M. and Huhtaniemi, I. 2008 In vitro bioassays for androgens and their diagnostic applications. Hum Reprod Update 14, 73-82.

Sahu, B., Pihlajamaa, P., Dubois, V., Kerkhofs, S., Claessens, F. and Jänne, O.A. 2014 Androgen receptor uses relaxed response element stringency for selective chromatin binding and transcriptional regulation in vivo. Nucleic Acids Res 42, 4230-40.

Schauwaers, K., De Gendt, K., Saunders, P.T., Atanassova, N., Haelens, A., Callewaert, L., Moehren, U., Swinnen, J.V., Verhoeven, G., Verrijdt, G. and Claessens, F. 2007 Loss of androgen receptor binding to selective androgen response elements causes a reproductive phenotype in a knockin mouse model. Proc Natl Acad Sci U S A 104, 4961-6.

Siiteri, P.K., Murai, J.T., Hammond, G.L., Nisker, J.A., Raymoure, W.J. and Kuhn, R.W. 1982 The serum transport of steroid hormones. Recent Prog Horm Res 38, 457-510.

Snyder, P.J., Bhasin, S., Cunningham, G.R., Matsumoto, A.M., Stephens-Shields, A.J., Cauley, J.A., Gill, T.M., Barrett-Connor, E., Swerdloff, R.S., Wang, C., Ensrud, K.E., Lewis, C.E., Farrar, J.T., Cella, D., Rosen, R.C., Pahor, M., Crandall, J.P., Molitch, M.E., Cifelli, D., Dougar, D., Fluharty, L., Resnick, S.M., Storer, T.W., Anton, S., Basaria, S., Diem, S.J., Hou, X., Mohler, E.R., 3rd, Parsons, J.K., Wenger, N.K., Zeldow, B., Landis, J.R. and Ellenberg, S.S. 2016 Effects of Testosterone Treatment in Older Men. N Engl J Med 374, 611-24.

Sonneveld, E., Jansen, H.J., Riteco, J.A., Brouwer, A. and van der Burg, B. 2005 Development of androgen- and estrogen-responsive bioassays, members of a panel of human cell line-based highly selective steroid-responsive bioassays. Toxicol Sci 83, 136-48.

Soto, A.M., Maffini, M.V., Schaeberle, C.M. and Sonnenschein, C. 2006 Strengths and weaknesses of in vitro assays for estrogenic and androgenic activity. Best Pract Res Clin Endocrinol Metab 20, 15-33.

Terouanne, B., Tahiri, B., Georget, V., Belon, C., Poujol, N., Avances, C., Orio, F., Jr., Balaguer, P. and Sultan, C. 2000 A stable prostatic bioluminescent cell line to investigate androgen and antiandrogen effects. Mol Cell Endocrinol 160, 39-49. 
van der Sluis, T.M., Bui, H.N., Meuleman, E.J., Heijboer, A.C., Hartman, J.F., van Adrichem, N., Boeve, E., de Ronde, W., van Moorselaar, R.J. and Vis, A.N. 2012a Lower testosterone levels with luteinizing hormone-releasing hormone agonist therapy than with surgical castration: new insights attained by mass spectrometry. J Urol 187, 1601-6.

van der Sluis, T.M., Meuleman, E.J., van Moorselaar, R.J., Bui, H.N., Blankenstein, M.A., Heijboer, A.C. and Vis, A.N. 2012b Intraprostatic testosterone and dihydrotestosterone. Part II: concentrations after androgen hormonal manipulation in men with benign prostatic hyperplasia and prostate cancer. BJU Int 109, 183-8.

Van Uytfanghe, K., Stockl, D., Kaufman, J.M., Fiers, T., Ross, H.A., De Leenheer, A.P. and Thienpont, L.M. 2004 Evaluation of a candidate reference measurement procedure for serum free testosterone based on ultrafiltration and isotope dilution-gas chromatography-mass spectrometry. Clin Chem 50, 2101-10.

Vermeulen, A., Verdonck, L. and Kaufman, J.M. 1999 A critical evaluation of simple methods for the estimation of free testosterone in serum. J Clin Endocrinol Metab 84, 3666-72.

Voet, A., Helsen, C., Zhang, K.Y. and Claessens, F. 2013 The discovery of novel human androgen receptor antagonist chemotypes using a combined pharmacophore screening procedure. ChemMedChem 8, 644-51.

Vos, M.J., Mijnhout, G.S., Rondeel, J.M., Baron, W. and Groeneveld, P.H. 2014 Sex hormone binding globulin deficiency due to a homozygous missense mutation. J Clin Endocrinol Metab 99, E1798-802.

Wilkinson, J.M., Hayes, S., Thompson, D., Whitney, P. and Bi, K. 2008 Compound profiling using a panel of steroid hormone receptor cell-based assays. J Biomol Screen 13, 755-65.

Wu, F.C., Tajar, A., Beynon, J.M., Pye, S.R., Silman, A.J., Finn, J.D., O'Neill, T.W., Bartfai, G., Casanueva, F.F., Forti, G., Giwercman, A., Han, T.S., Kula, K., Lean, M.E., Pendleton, N., Punab, M., Boonen, S., Vanderschueren, D., Labrie, F. and Huhtaniemi, I.T. 2010 Identification of late-onset hypogonadism in middle-aged and elderly men. N Engl J Med 363, 123-35.

Wu, T.S. and Hammond, G.L. 2014 Naturally occurring mutants inform SHBG structure and function. Mol Endocrinol 28, 1026-38. 
Zakharov, M.N., Bhasin, S., Travison, T.G., Xue, R., Ulloor, J., Vasan, R.S., Carter, E., Wu, F. and Jasuja, R. 2015 A multi-step, dynamic allosteric model of testosterone's binding to sex hormone binding globulin. Mol Cell Endocrinol 399, 190-200. 